Boise State University

ScholarWorks

8-2013

\title{
Anticipating Stream Ecosystem Responses to Climate Change: Toward Predictions That Incorporate Effects via Land-Water Linkages
}

J. M. Davis

U.S. Environmental Protection Agency

C. V. Baxter

Idaho State University

E. J. Rosi-Marshall

Cary Institute of Ecosystem Studies

J. L. Pierce

Boise State University

B. T. Crosby

Idaho State University 
1 Running head: Indirect effects of climate change on streams

2

3

$11{ }^{1}$ Stream Ecology Center, Dept. of Biological Sciences, Idaho State University, Pocatello, ID 83209

18 Author contributions:

19 JMD, CVB, EJRM, JLP, and BTC conceived the research question and developed the ecosystem

20 model. JMD and CVB wrote the manuscript with contributions from EJRM, JLP, and BTC.
${ }^{2}$ Cary Institute of Ecosystem Studies, Millbrook, NY 12545

${ }^{3}$ Dept. of Geosciences, Boise State University, Boise, ID 83725

${ }^{4}$ Dept. of Geosciences, Idaho State University, Pocatello, ID 83209

*Corresponding author: Phone: 706-372-4136, Email: hexatoma@gmail.com

21 


\section{Abstract}

24 Climate change (CC) is predicted to increase the frequency and severity of natural disturbances

25 and shift distributions of terrestrial ecosystems. Western North America, in particular, is predicted

26 to experience CC-induced alteration of forest boundaries due to changes in wildfire, debris flows,

27 and insect outbreaks. Because stream ecosystems are coupled to terrestrial ecosystems via flows of

28 material and energy, such shifts in terrestrial disturbance regimes and ecosystem distributions will

29 likely affect stream ecosystems. However, predictions of stream responses to CC have not

30 incorporated these potentially important effects of altered terrestrial processes. Here, we use a

31 conceptual ecosystem model to assess how responses of forested stream ecosystems to CC will be

32 related to not only direct effects of thermal and hydrologic shifts, but also indirect effects of altered

33 terrestrial processes (i.e., disturbance regimes and vegetation structure). Because effects of terrestrial

34 processes on streams have been well-studied in contexts largely independent of CC research, we

35 synthesize and apply this knowledge to generate predictions of how CC-induced alterations of

36 terrestrial ecosystems may change stream ecosystem structure and function. Our analysis indicates

37 that altered terrestrial processes will change terrestrial inputs, biotic production, and carbon

38 dynamics, yielding greater climate sensitivity than would be expected based solely on shifts in

39 temperature and precipitation regime. It also indentified uncertainties that presently constrain

40 predictions of some responses, such as ecosystem metabolism and carbon export. Therefore,

41 accurate prediction of $\mathrm{CC}$ effects on temperate stream ecosystems may be strongly coupled to the

42 accuracy of predictions for long-term changes in terrestrial processes.

43

44 Keywords: climate change, wildfire, disturbance regime, stream food web, qualitative model 

encompass possible feedbacks and interactions, as they may influence the magnitude and direction of the overall effects of CC. For example, when responses of vegetation and disturbance regimes to CC are not integrated into predictive models, models may under- or overestimate projected air temperature increases due to CC (Goetz and others 2007; Kurz and others 2008). Wildfires that convert coniferous forests to grasslands or deciduous forests may increase albedo and negative

53 feedbacks to CC (Goetz and others 2007). Conversely, vegetation changes due to insect outbreaks

54 or wildfire can reduce carbon storage, providing positive feedbacks to CC (Goetz and others 2007;

55 Kurz and others 2008). A range of terrestrial, freshwater, and marine ecosystems will be sensitive to warming (Rosenzweig and others 2008), but such interactions that amplify or dampen expected temperature shifts will pose a challenge to accurate predictions of these ecosystem sensitivities.

62 research largely has focused on assessing responses to changing temperature and flow, there is ample

63 evidence that CC may alter aquatic species phenologies (Thackeray and others 2010), distributions

64 (Sweeney and others 1992), and interactions (Woodward and others 2010). However, CC is

65 occurring coincidently with other ecological changes (e.g., land-use change and nutrient enrichment)

66 that are known to affect streams and may magnify or attenuate stream responses to CC (Kaushal

67 and others 2010; Moss 2010). For instance, simultaneous nutrient enrichment and higher water

68 temperatures led to severe deoxygenation and increased fish mortality beyond what was expected

69 based on these changes alone (Moss 2010). Similarly, stream acidification negated thermal effects,

70 such that stream warming over a 25 -yr period reduced invertebrate abundance in reference streams, 
71 but not in acidified streams (Durance and Ormerod 2007). Thus, predicted effects of CC could be

72 over- or underestimated if the ecological context in which changes are occurring is not considered.

73 Overall responses of stream ecosystems to CC may be underestimated if predictions do not take

74 into account the consequences of shifts in forest ecotones and terrestrial disturbance regimes, such

75 as the frequency and magnitude of wildfires, insect outbreaks, and drought, that are accompanying

76 CC (Pierce and others 2004; Bentz and others 2010; Westerling and others 2011). Because terrestrial

77 and stream ecosystems are linked via inputs of nutrients, sediment, organic matter, and light flux,

78 changes to terrestrial ecosystems can affect streams (Likens and Bormann 1974; Hynes 1975) and

79 even small alterations of forest composition may affect stream responses to global change (Ball and

80 others 2010). As natural disturbances can have dramatically larger effects on terrestrial ecosystems

81 and inputs, alterations of disturbance regimes by CC will likely change streams. For instance,

82 wildfire and fire-related debris flows (i.e., liquefied landslides that scour stream channels) can

83 remove canopy cover, increasing light flux and stream temperatures and affecting stream biota

84 (Dunham and others 2007; Romme and others 2011). Also, greater disturbance activity due to CC

85 may not just alter species ranges and forest assemblages, but will likely move ecosystem boundaries

86 and convert forests to shrub-grasslands in regions worldwide (Shafer and others 2001; Williams and

87 others 2007; Frelich and Reich 2010). Between 10-50\% of global land area is highly vulnerable to

88 CC and may exhibit shifts in ecosystem distributions up to $400 \mathrm{~km}$ in latitude (Gonzalez and others

89 2010). Thus, CC-induced alteration of terrestrial processes (i.e., disturbance regimes and ecosystem

90 distributions) will likely change the context of CC and our ability to predict stream responses.

91 At present there are few CC studies upon which to develop predictions that integrate both direct

92 and indirect effects of CC on streams, but that does not mean the scientific community has no basis

93 for generating such predictions. There is a rich history of research that has been dedicated to

94 understanding ecological linkages between streams and their watersheds (e.g., Likens and Bormann 
95 1974; Hynes 1975; Ball and others 2010), and the principals that have emerged should be brought to

96 bear on this challenge. Effects of altered terrestrial processes on streams have been well-studied,

97 albeit in contexts largely independent of CC (e.g., wildfire and deforestation; Gresswell 1999;

98 Kiffney and others 2004; Romme and others 2011). Their importance has also begun to be assessed

99 in the arctic where thermal increases may be greatest. For instance, positive effects of warming on

100 stream production may be partly offset by concomitant increases in sedimentation due to permafrost

101 thawing and hillslope failure (Bowden and others 2008). Similar interactions may occur in temperate

102 biomes, but research in this region largely has focused on effects of changing temperature and flow

103 without explicitly integrating impacts of altered terrestrial processes. However, by leveraging

104 knowledge of how terrestrial processes, in general, can affect streams, we can begin to predict how

105 similar CC-induced shifts in such processes may alter stream structure and function.

106 Research objectives: Here, we evaluate whether predicting long-term effects of CC on forested

107 temperate streams requires an approach that not only encompasses the direct effects of thermal and

108 flow regime shifts, but also integrates indirect effects associated with altered terrestrial disturbance

109 regimes (e.g., drought, wildfires, beetle outbreaks, and debris flows) and ecosystem distributions

110 (Fig. 1). We addressed this question in the context of mountainous river basins of western North

111 America, a region where stream responses to terrestrial disturbances and the direct effects of CC

112 have been well-studied. First, by reviewing current evidence, we show that CC is shifting many

113 mountainous regions from a snow- to rain-dominated precipitation regime, subsequently increasing

114 the frequency, severity, and spatial extent of natural disturbances over the time span considered

115 (150-200 years). We selected this time span because it is comparable to historic fire return intervals

116 (200-400 yrs) and time required for mixed conifer forests to reach old-growth status (200-500 yrs;

117 Oliver 1981; Arno and others 1985; Nelson and Pierce 2010). Although effects of these changes

118 may differ over shorter periods, focusing on longer periods allowed assessment of effects once 
119 forests have converted to a new ecosystem type. Next, we show that greater disturbance activity is

120 predicted to alter ecosystem distributions and shift the dominant ecosystem types drained by river

121 networks (Appendix 1), alterations that will likely have consequences for streams.

122 Using the extensive literature that evaluates how terrestrial processes can affect streams via

123 changes in temperature and inputs of sediment, nutrients, and organic matter, we develop a

124 conceptual ecosystem model that assessed how similar CC-induced shifts in terrestrial disturbances

125 and ecosystem distributions could affect terrestrial inputs (Fig. 2). Based on the model, we predicted

126 how changes in such inputs could affect stream temperature, organic matter standing crop, substrate

127 stability, and consequences for stream biota and carbon dynamics (Fig. 3). By contrasting

128 predictions that integrated indirect effects of $\mathrm{CC}$ on streams (i.e., terrestrial processes) with those

129 based only on thermal and precipitation regime shifts, we assessed if the net effect of CC may be

130 under- or overestimated. Predictions are most relevant to mountainous river basins of western

131 North America, but similar changes in hydrology, disturbance regimes, and ecosystem boundaries

132 are expected worldwide (Barnett and others 2005; Flannigan and others 2009; Bentz and others

133 2010; Gonzalez and others 2010). Thus, our analysis was intended to broadly inform predictions of

134 direct and indirect effects of CC across a range of regions and provide guidance for future research.

135 We used a qualitative approach, as first proposed by Levins (1966), to develop the conceptual

136 ecosystem model and compare direct and indirect effects of CC on streams. Qualitative models can

137 provide a framework for integrating across disciplines to assess responses of complex systems to

138 perturbation, especially when magnitudes of some parameters are unknown (Justus 2005). This

139 heuristic approach is a valuable first step in generating predictions, augmenting quantitative models

140 that often focus on subsets of a system, and identifying uncertainties that will require future study.

\section{Effects on terrestrial processes}

142 Effects on thermal and precipitation regimes: Climate models for western North America project a 1- 
$14355^{\circ} \mathrm{C}$ increase in air temperature, increases in winter precipitation, and declines in summer rainfall by

1442080 (Mote and Salathe 2010). Such changes will likely affect mountain streams in this region as

145 they typically rely on winter snowpack to sustain baseflow during dry summers (Barnett and others

146 2005; Stewart 2009). For example, higher air temperatures have reduced snowpack as more

147 precipitation occurs as rain (Knowles and others 2006); changes projected to increase the frequency

148 of winter floods and decrease summer baseflow (Stewart 2009). Warming also has shifted spring

149 snowmelt earlier and reduced the size of spring run-off in this region (Stewart 2009; Kunkel and

150 Pierce 2010). From 1948-2002, snowmelt occurred 10-20 days earlier and will be even earlier by

1512100 (Stewart and others 2004). Thus, CC may not affect total annual precipitation, but is expected

152 to change when and how it falls, increasing the prevalence of winter floods and terrestrial

153 disturbances due to transitions from snowpack accumulation to rain-on-snow events (Fig. 1).

154 Effects on terrestrial disturbances: Because air temperature and precipitation regulate wildfire activity

155 (Gedalof and others 2005), reduced snowpack and earlier snowmelt have increased summer drought

156 stress and the frequency and severity of wildfire (Westerling and others 2006) and fire-related debris

157 flows (Pierce and others 2004). Wildfire area in western North America is expected to increase 54\%

158 due to CC, with the Rocky Mountains projected to see some of the largest increases $(175 \%$;

159 Spracklen and others 2009) and loss of coniferous forests in some areas by ca. 2050 (Westerling and

160 others 2011). Increased wildfire will likely be coupled with more frequent debris flows. Debris

161 flows occur in unburned streams, but their magnitude and probability of occurrence increases post-

162 fire (Cannon 2001; Miller and others 2003). In one study, 54\% of streams that were affected by

163 wildfire experienced a debris flow within $30 \mathrm{yrs}$ of fire, in contrast to $12 \%$ of unburned streams, and

164 effects were still detectable $>100$-yrs post-debris flow (May and Gresswell 2003). Paleoecological

165 records have found similar correlations between climate, fire, and debris flows (Pierce and others

166 2004), indicating that current warming also may increase their frequency (Fig. 1). 
167 Drought stress can increase vulnerability of trees to insect infestations (Dukes and others 2009;

168 Bentz and others 2010). Warming of $1-2^{\circ} \mathrm{C}$ increased the frequency of insect outbreaks in high

169 latitude and elevation habitats that previously did not experience large outbreaks (Raffa and others

170 2008). Even in areas that historically experienced outbreaks, outbreaks persist longer, first due to

171 successive warm summers that stimulate insect reproductive cycles but also to warmer winters that

172 minimize cold-induced mortality (Raffa and others 2008; Bentz and others 2010). Thus, mountain

173 pine beetle (Dendroctonus ponderosae) outbreaks over the past decade have affected $>25$ million ha

174 throughout western North America, with future increases projected (Bentz and others 2010).

175 Effects on vegetation structure: Changes in disturbance regimes will likely influence forest composition

176 and regeneration (Shafer and others 2001; Williams and others 2007). For example, paleoecological

177 studies in parts of western North America have shown that previous extended droughts correlated

178 with greater extent of shrub-grassland species (Beiswenger 1991; Huerta and others 2009; Nelson

179 and Pierce 2010; Whitlock and others 2011). Modern CC may lead to similar patterns as it has been

180 implicated in large-scale tree mortality, shifts in forest composition (Bentz and others 2010; Williams

181 and others 2010), and reduced tree basal area and canopy cover in western North America (van

182 Mantgem and others 2009; Clifford and others 2011). Reductions in seedling recruitment due to CC

183 are projected to decrease the extent of floodplain forests in North America (Rood and others 2008).

184 More frequent insect outbreaks linked to CC also moved ecotones up to $2 \mathrm{~km}$ over a $5 \mathrm{yr}$ period in

185 southwestern North America (Allen and Breshears 1998), decreased canopy cover by 55\% in a 2 yr

186 period, and eliminated increases in forest cover that occurred since the 1930s (Clifford and others

187 2011). Even when forests currently exhibit no signs of change, future shifts may still occur rapidly.

188 For instance, trees can be long-lived and have lagged population responses to ecological change;

189 thus, forests may persist despite ecological changes that reduce, or eliminate, seedling recruitment

190 (Brubaker 1986; Turner 2010). In fact, forest cover can be committed to a $50 \%$ decline before any 
191 signs of impending dieback are detected (Jones and others 2009). As greater drought sensitivity of

192 low elevation forests can move ecotones upslope (Knutson and Pyke 2008) and modern CC may

193 lead to conditions similar to past severe droughts of the Holocene (Cook and others 2004), the

194 extent of shrub-steppe at low elevations is likely to increase in the future (Fig. 1; Appendix 1).

195 Increased wildfire activity may accelerate forest conversion as it can rapidly convert stressed

196 ecosystems to new ecosystem types (Turner 2010). Under past climate regimes, mixed conifer

197 forests in western North America typically matured to pre-fire conditions in 100-200 yrs (Oliver

198 1981; Arno and others 1985), but the return interval for a stand-replacing fire was even longer (200-

199400 yrs; Minshall and others 1989; Meyer and others 1992; Svenson 2010). This allowed old-growth

200 forests to regenerate after wildfires. However, forests may not reestablish post-fire and may shift to

201 a new ecosystem type if regeneration rates slow or fire return intervals shorten (Westerling and

202 others 2011). This potential may increase as many trees at low elevations in western North America

203 germinated during a cooler, wetter interval known as the 'Little Ice Age' (1700-1900 AD; Grove

204 1988; Nelson and Pierce 2010). Preliminary evidence also suggests negligible post-fire seedling

205 recruitment at low elevations in Idaho's Salmon River basin (Nelson and Pierce 2010), findings that

206 echo the CC-induced 'savannification' of prairie-forest boundaries (Frelich and Reich 2010). If

207 trends persist or accelerate, it could convert entire ecosystems, shift forests upslope, and alter the

208 dominant ecosystem type in many river basins of western North America (Fig. 1).

\section{Effects on resource flows to streams}

210 Because streams rely on material and energy flows from terrestrial ecosystems (Minshall and

211 others 1992; Webster and Meyer 1997), we now evaluate how altered terrestrial processes may affect

212 stream temperature, light flux, and inputs of nutrients, sediment, and organic matter (Figs. 1 and 2);

213 integrate direct and indirect effects into our ecosystem model (Fig. 3); and compare net effects on

214 stream structure and function (Tables 1-3). Our analysis was based on considerable evidence 
215 examining stream responses to wildfire and changes in vegetation structure, but there are few studies

216 assessing stream responses to beetle outbreaks. We reason that beetle outbreaks may lead to similar

217 patterns in tree mortality observed with stand-replacing fires and subsequently many similar

218 consequences for streams, though this remains to be corroborated by future investigations.

219 Stream temperature: Higher air temperatures have warmed streams by $0.009-0.077^{\circ} \mathrm{C}$ per year in

220 many ecoregions (Kaushal and others 2010). However, wildfire can also warm streams as it reduces

221 canopy cover and thermal insulation (Royer and Minshall 1997; Gresswell 1999). A study in western

222 North America showed that thermal responses of streams to higher air temperatures were 2-3X

223 greater for burned vs. unburned streams (Isaak and others 2010). As there is considerable evidence

224 that outbreaks can lead to comparable tree mortality and canopy loss throughout western North

225 America (Bentz and others 2010; Williams and others 2010), we speculate that increased pine beetle

226 activity may similarly warm streams. Streams that experienced wildfire and a subsequent debris flow

227 also had average maximum temperatures that were $8^{\circ} \mathrm{C}$ higher than unburned streams $(23.5$ vs.

$\left.228 \quad 15.6^{\circ} \mathrm{C}\right)$ and $4^{\circ} \mathrm{C}$ higher than burned streams $\left(23.5\right.$ vs. $19^{\circ} \mathrm{C}$; Dunham and others 2007). Under past

229 climates that promoted regeneration of forest canopy, elevated post-disturbance temperatures were

230 short in duration (Minshall and others 1989). However, if CC reduces forest regeneration and shifts

231 landscapes to shrub-steppe, post-disturbance thermal effects may be prolonged (Table 1; Fig. 3).

232 Thus, altered terrestrial processes may reinforce stream responses to higher air temperatures,

233 warming streams more than would be expected based on direct effects alone.

234 Light flux: Greater light flux can increase stream temperatures, but few studies have explicitly

235 assessed effects of CC on light regimes. However, there is ample evidence that CC may increase

236 light flux to forested streams, which could have effects that extend beyond temperature increases

237 (i.e., increased light can stimulate primary production). Severe wildfire can reduce canopy cover and

238 increase light flux to the stream surface (Gresswell 1999; Romme and others 2011). Five years post- 
239 fire, light flux to streams that experienced severe wildfire was $2 \times$ greater than to unburned streams

240 (Malison and Baxter 2010), but light flux typically peaks soon after wildfire because of rapid

241 regeneration of riparian vegetation (Fig. 2; Romme and others 2011). Due to comparable loss of

242 canopy cover, we expect that temporal patterns of light flux responses would be similar after beetle

243 outbreaks. In contrast to past climate regimes where canopy cover quickly regenerated, light flux in

244 watersheds experiencing reduced or no forest regeneration might remain elevated (Fig. 2). A

245 consequence may be that effects of terrestrial disturbances on light regimes that were historically

246 short-lived may become more chronic. Thus, terrestrial processes may increase light flux more than

247 would be expected based solely on temperature and precipitation effects (Table 1; Figs 2 and 3).

248 Nutrient inputs: Reductions in snow depth and thermal insulation can increase the duration and

249 depth of soil freezing (Brooks and Williams 1999; Groffman and others 2011). This may increase

250 soil leaching, and nitrogen and phosphorus inputs to streams (Brooks and Williams 1999; Fitzhugh

251 and others 2001), but not in all cases (Groffman and others 2011). Nutrient leaching responses to

252 freezing were lower with higher availability of dissolved organic carbon (DOC), likely due to greater

253 microbial activity and nutrient sequestration (Groffman and others 2011). Leaching also differed

254 with forest type (Fitzhugh and others 2001). Despite some contrasting results, evidence suggests the

255 potential for temperature and precipitation regime shifts to increase nutrient inputs (Table 1).

256 Altered terrestrial processes may not change increases in nutrient inputs expected due to thermal

257 and precipitation shifts. Nutrient inputs to streams can increase immediately post-fire (Spencer and

258 others 2003; Stephan and others 2012). However, soil nutrient retention increases as forests regrow

259 (Vitousek and Reiners 1975) and inputs can return to pre-fire levels over longer periods (Spencer

260 and others 2003; Romme and others 2011), a pattern that may be mirrored during regeneration after

261 beetle outbreaks. Even if forest regeneration declines and shifts them to shrub-steppe, it may not

262 affect long-term nutrient inputs. Invasion of grasslands by woody plants had little effect on soil 
263 nutrient availability due to faster microbial and nutrient turnover in grasslands (Booth and others

264 2005; McKinley and others 2008). Rapid turnover would likely sequester leachates and reduce

265 export. On the other hand, freezing effects on leaching differed between sugar maple and yellow

266 birch forests (Groffman and others 2011), suggesting the potential for vegetation type to influence

267 responses and the need for more studies. Thus, soil freezing may increase nutrient inputs, but there

268 is currently little evidence that terrestrial processes will substantially affect inputs (Table 1; Fig. 3).

269 Sediment inputs: Altered disturbance regimes due to CC likely will affect sediment inputs. Over

270 long timescales $\left(10^{3}\right.$ to $\left.10^{4} \mathrm{yr}\right)$, extended drought can increase the frequency and magnitude of large

271 sedimentation events. For instance, prolonged warming and drying during the 'Medieval Climatic

272 Anomaly' (ca. 950-1250 AD) produced debris flows throughout the northern Rocky Mountains

273 (Meyer and others 1992; Pierce and others 2004; Nelson and Pierce 2010). Erosion rates in central

274 Idaho during the Holocene (ca. last $10^{4} \mathrm{yr}$ ) also have not been constant through time and have been

275 related to climate (Kirchner and others 2001; Meyer and others 2001; Pierce and others 2004). As

276 droughts induced by current CC may reach the severity of those accompanying earlier Holocene

277 warming (Cook and others 2004), sediment inputs may increase in mountainous regions. Greater

278 fire activity may further increase inputs. For example, considerable evidence shows that wildfires can

279 increase sediment inputs and reduce instream sediment storage, particularly during fire-related debris

280 flows (Cannon 2001; May and Gresswell 2003; Wondzell and King 2003). Because sediment storage

281 increases linearly with instream wood (May and Gresswell 2003), forest regrowth after disturbance

282 may reduce inputs and increase storage. However, effects have been detected up to 150 yrs post-

283 debris flow (May and Gresswell 2003). Therefore, even when forests regenerate, greater wildfire and

284 debris-flow activity may increase sediment inputs, yet decrease storage (Table 1; Figs. 2 and 3).

285 Given the importance of forest regeneration for the recovery of sediment dynamics, conversion

286 to shrub-steppe likely would magnify sediment responses. Sediment inputs to streams are a function 
287 of forces that resist hillslope erosion (e.g., rooting depth and density, soil cohesion, and friction) and

288 forces that facilitate sediment movement (e.g., slope and soil saturation). On forested slopes, greater

289 soil cohesion from tree roots and soil moisture can reduce sediment inputs (Schmidt and others

290 2001). Shrub-steppe had higher baseline sediment inputs due to reduced rooting depth, combined

291 with increased raindrop impact and less water infiltration. Shrub dominated slopes also exhibited

292 more frequent, but lower magnitude, sheetflood events (i.e., sediment-rich floods that deposit

293 sediment when channels become unconfined), rather than rarer large magnitude slope failures and

294 debris flows on forested slopes (Pierce and others 2004; K. Riley and J. Pierce unpubl. data).

295 Sediment retention also may decline due to reduced forest regrowth that reduces wood inputs to

296 stream channels (see below). Thus, changes in terrestrial processes would be expected to sustain

297 higher sediment inputs and reduced sediment storage for longer periods (Table 1; Figs. 2 and 3).

298 Terrestrial organic matter inputs: Although altered precipitation and thermal regimes may affect

299 inputs of organic matter (i.e., leaf litter and DOC) and wood to streams, changes will result from

300 greater terrestrial productivity and drought stress. For instance, higher air temperatures can increase

301 terrestrial plant production (Wu and others 2011), which may increase availability and inputs of

302 organic matter. Drought stress, however, can also increase tree mortality (van Mantgem and others

303 2009; Clifford and others 2011), which can attenuate, or reverse, greater plant production (Wu and

304 others 2011). This greater mortality may still increase inputs if forests regenerate post-drought and

305 plant biomass turns over faster. Evidence also suggests that reduced snowpack can increase DOC

306 leaching in soils (Groffman and others 2011) and may increase inputs to streams, but others have

307 found no DOC response (Hentschel and others 2009). However, leaching from instream organic

308 matter can be an important DOC source (Meyer 1998); thus, DOC inputs may still increase as

309 inputs of wood and detritus increase. If forests regenerate post-disturbance, CC-induced shifts in

310 terrestrial processes would be expected to increase organic matter inputs (Table 1; Fig. 3). 
311 Reduced forest regeneration and shifts to shrub-steppe would likely decrease inputs of organic

312 matter. Because of greater canopy cover, forested streams have higher inputs and standing crop

313 than non-forested streams (Webster and Meyer 1997). For instance, inputs to Camp Creek, a

314 coniferous-forested stream in Idaho's Salmon River basin, are orders of magnitude higher than

315 inputs to Deep Creek, a shrub-grassland stream in southeastern Idaho (339.9 vs. 2.4 g AFDM m yr $^{-2}$

$312^{1}$ ) (Minshall and others 1992; Webster and Meyer 1997). DOC inputs may similarly decline because

317 of reductions in detritus inputs (e.g., Meyer 1998). Consequently, organic matter inputs would be

318 predicted to decrease in scenarios when forest regeneration and cover decline (Table 1; Fig. 3).

319 Altered terrestrial processes will likely affect wood inputs, which can retain organic matter and

320 maintain habitat in high gradient streams (Megahan 1982; Gurnell and others 2002). Wildfire can

321 increase short-term inputs, as fire-killed snags from both streamside and hillslope sources are

322 recruited (the latter via deposits from landslides and debris flows) into stream channels (Fig. 2;

323 Benda and others 2003; Robinson and others 2005; Romme and others 2011). Long-term inputs

324 return to pre-fire levels as the pool of snags is depleted and trees regenerate, patterns likely to occur

325 after large-scale tree mortality due to beetle outbreaks. Conversely, debris flows can reduce the

326 amount of wood in low to mid-order stream channels by removing riparian vegetation and sources

327 of wood (May and Gresswell 2003; Cover and others 2010), such that the dominant habitat can be

328 bedrock even a 100 yrs post-debris flow (May and Gresswell 2003). Despite short-term effects of

329 terrestrial disturbances, long-term wood inputs and standing crop recovered to pre-disturbance

330 levels as forests regenerated under past climate regimes, a process that could take more than a

331 century (Minshall and others 1989; Jones and Daniels 2008). Reduced regeneration and conversion

332 to a shrub-steppe may slow this recovery, reducing inputs and standing crop (Fig. 2). Shrubs can

333 contribute woody debris and experience more frequent wildfires (fire return interval of 70-200 years;

334 Baker 2006), but their smaller stature indicates that alternate wood sources (i.e., twigs and small 
335 branches) may be inadequate substitutes for trees. Moreover, expected replacement of woody plants

336 by annual invasive grasses (e.g., cheatgrass: Bromus tectorum) following fire (Billings 1994) may further

337 reduce fire return intervals and wood inputs. Thus, greater disturbance activity and reduced forest

338 regeneration may override greater wood inputs predicted with CC-induced increases in drought and

339 terrestrial productivity (Table 1; Figs. 2 and 3). Persistent reductions in inputs may ultimately reduce

340 wood standing crop in stream channels and decrease organic matter retention, results that would not

341 be predicted without incorporating terrestrial processes into predictive frameworks.

\section{Effects on instream structure and function}

343 Autotrophic production: Autotrophs may exhibit complex responses to CC as their production is

344 related to various factors (e.g., flow, nutrients, light, and substrate stability; Larned 2010) that will

345 likely change. Higher stream temperatures may increase autotrophic production as it is positively

346 related to temperature (Fig. 3; Mulholland and others 2001; Yvon-Durocher and others 2010). Flow

347 effects may vary seasonally as high flows, in general, decrease primary production and low flows

348 increase it (Uehlinger and Naegeli 1998; Marcarelli and others 2010). A shift to a rain-dominated

349 hydrology that increases frequency of winter floods may decrease productivity in the winter, whereas

350 it may increase in the summer due to baseflow reductions. Post-flood recovery of production also

351 can vary seasonally, such that recovery is slower in the winter when temperature and light flux are

352 lower (Uehlinger 2000). Annual production may decrease if declines in winter production are

353 sustained over longer periods and are larger than increases in the summer (Table 2; Fig. 3).

354 Shifts in terrestrial processes will likely affect stream autotrophs. As photo-autotrophs can be

355 light limited (Mulholland and others 2001; Kiffney and others 2004), terrestrial disturbances and

356 shifts in vegetation structure that reduce canopy cover over streams may increase primary

357 production (Fig. 3). There are few data assessing effects of wildfire on primary production in

358 temperate streams, but it increased post-fire in boreal forest streams (Betts and Jones 2009). Algal 
359 biomass was also higher in burned vs. unburned forested streams in Idaho (Minshall and others

360 2001). Primary production was higher 10-yrs after a debris flow, but biomass was lower (Cover and

361 others 2010). However, responses return to pre-disturbance levels as forests regenerate (Minshall

362 and others 2001; Cover and others 2010), and we expect that autotrophs would respond similarly to

363 beetle outbreaks due to comparable trends in tree mortality and regeneration. Given the importance

364 of tree regeneration for post-disturbance recovery of stream primary production, reduced forest

365 regeneration may sustain higher light flux and production over longer periods (Table 2). However,

366 changes also may reduce primary production. As wildfire and debris flows can increase sediment

367 inputs (Pierce and others 2004), they may increase turbidity, which can attenuate light flux to the

368 benthos and reduce primary production (Young and Huryn 1996; Izagirre and others 2008).

369 Sediment also can increase abrasion and reduce algal biomass (Biggs and others 1999; Francoeur and

370 Biggs 2006). In Yellowstone National Park, sedimentation was thought to be a primary reason that

371 short-term increases in algal biomass did not persist with post-fire increases in light flux (Romme

372 and others 2011), suggesting increased sediment inputs could decrease production by reducing light

373 flux to the benthos and increasing abrasion (Table 2; Fig. 3).

374 The net response of autotrophic production will depend on the relative magnitude of the positive

375 (e.g., light) and negative (e.g., sediment) effects. Productivity may increase if light flux to the stream

376 surface is more important, but decrease if turbidity is more important. Despite such uncertainty, we

377 speculate that the net effect of these factors will ultimately increase primary production more than

378 would be expected based on direct effects alone (Table 2; Fig. 3).

379 Heterotrophic microbial production: As temperature and flow contribute to regulating microbial

380 production and respiration (Uehlinger 2000; Allen and others 2005), CC is expected to directly alter

381 production of heterotrophic microbes (i.e., fungi and bacteria; hereafter referred to as 'microbes').

382 In short-term experiments, higher water temperatures increased microbial production and 
383 respiration, but respiration increased more (Sand-Jensen and others 2007). However, microbes can

384 exhibit thermal adaptation such that respiration may be resilient to temperature increases, as has

385 been shown by long-term soil warming experiments (Bradford and others 2008). Increases in

386 respiration also may be transitory if it is ultimately limited by photosynthesis and the processes are in

387 steady state (Allen and others 2005). Yet, respiration in many streams is not limited by aquatic

388 primary production because microbes rely on inputs of terrestrial or stored organic matter

389 (Mulholland and others 2001). In such cases, respiration increases may be sustained (Yvon-

390 Durocher and others 2010). Because warming is expected to increase microbial respiration in

391 heterotrophic streams (Acuna and Tockner 2010; Boyero and others 2011) and many forested

392 streams are heterotrophic, microbial production may increase in forested streams considered in our

393 model. Such thermal effects may be attenuated by more frequent floods because floods, in general,

394 decrease microbial respiration and production (Uehlinger and Naegeli 1998; Uehlinger 2000).

395 Hence, CC will directly affect microbial responses via altered temperature and flow (Table 2; Fig. 3).

396 Terrestrial processes will likely alter microbial responses as they can affect factors important for

397 maintaining microbial populations (e.g., nutrients, substrate stability, detritus availability; Bott and

398 others 1985; Uehlinger 2000; Findlay 2010). Reduced inputs of terrestrial organic matter may

399 increase resource limitation of microbes, but increases in aquatic primary production could stimulate

400 microbial production. However, an interbiome comparison of streams found a weak relationship

401 between respiration and primary production (Mulholland and others 2001), indicating that increased

402 primary production may have little impact. Also, microbial activity in a forested stream of eastern

403 North America, as measured by ecosystem respiration (ER), was primarily regulated by leaf detritus

404 availability and was weakly related to temperature (Roberts and others 2007). Consequently,

405 assessments of microbial responses should integrate changes in inputs and retention of organic

406 matter, which can be affected by large wood and interactions between fire and flow (Gurnell and 

respiration up to 20 yrs post-fire (Robinson and others 2005); however, we expect that microbial production will decrease over longer time scales. For instance, high flows decreased organic matter and wood standing crop in burned, but not in unburned streams (Arkle and others 2009), patterns

411 that also may be observed after large-scale beetle outbreaks. Reduced forest regeneration will also

412 likely decrease microbial production. As detritus inputs and standing crop were lower in shrub-

413 grassland streams (Webster and Meyer 1997), reduced forest regeneration and altered disturbance

414 regimes may decrease detritus availability, especially if wood inputs decrease. Altered terrestrial

415 processes may amplify resource limitation of microbes, subsequently decreasing their production

416 despite increases expected in response to temperature and precipitation alone (Table 2; Fig. 3).

417 Consumer production: Temperature increases are predicted to reduce taxa richness (Durance and

418 Ormerod 2007) and alter community composition of stream animals (Poff and others 2010), but

419 biomass and production responses are uncertain (Hogg and Williams 1996; Durance and Ormerod

420 2007). Biomass may decline because warming can increase respiration rates, reducing growth

421 efficiency and body size (Sweeney 1978; Woodward and others 2010). Secondary production, which

422 integrates several consumer metrics (i.e., abundance, biomass, and growth rate), may subsequently

423 increase due to higher temperatures and smaller body sizes (Fig. 3; Benke and Huryn 2010). Thus,

424 stream warming may decrease consumer biomass, but increase production (Table 2).

425 Shifts to a rain-dominated hydrology will likely affect consumers (Poff and others 2010). As

426 many stream biota in western North America adapted to past flow regimes that exhibited low winter

427 flow and predictable spring run-off, they developed life-history traits to minimize impacts of

428 seasonal high flows (Harper and Peckarsky 2006). However, earlier spring run-off can decouple

429 ecological cues, reduce populations of taxa that depend on predictable flow (Harper and Peckarsky

430 2006; Poff and Zimmerman 2010), and increase populations of those resistant to substrate- 
431 mobilizing floods (Poff and others 2010). Because many disturbance-resistant taxa are small-bodied

432 (e.g., Chironomidae larvae; Benke and Huryn 2010), shifts in flow regime that reduce substrate

433 stability may increase production. For example, although biomass was similar, secondary production

434 was ca. $1.6 \times$ greater in an Idaho stream with ca. $12 \times$ greater flow variability than in a paired stream;

435 differences were driven by dominance of disturbance-resistant taxa (Robinson and Minshall 1998).

436 Sycamore Creek, an open-canopy desert stream in the southwestern United States, also had high

437 production despite high thermal and flow variability (Jackson and Fisher 1986). Thus, shifts in flow

438 regime may alter composition, reduce biomass, and increase secondary production (Table 2; Fig. 3).

439 Terrestrial processes will likely affect consumer production in streams as it is governed by many

440 factors (i.e., food quantity and quality, temperature, flow, and substrate stability; Benke and Huryn

441 2010; Poff and Zimmerman 2010) that are predicted to change. Wildfire may increase consumer

442 production because it can increase the biomass (Minshall and others 2001; Malison and Baxter 2010)

443 and dominance of disturbance-resistant taxa (Vieira and others 2004; Romme and others 2011). In

444 addition, some coldwater-adapted taxa can persist in burned streams, despite warmer stream

445 temperatures (Dunham and others 2007). Consumer biomass and production were also higher in

446 open vs. closed canopy streams, likely due to greater autotroph production (Behmer and Hawkins

447 1986; Kiffney and others 2004); effects that may be mirrored when beetle outbreaks decrease tree

448 cover. Thus, increases in consumer respiratory demands and thermal stress expected with CC

449 (Woodward and others 2010) may be partly offset by greater autotrophic production, increasing

450 their production more than would be predicted from direct effects alone (Fig. 3).

451 Although terrestrial processes may increase consumer production via some mechanisms, these

452 changes also may have negative consequences for consumers. Sedimentation can be an important

453 source of stream impairment that negatively affects many stream consumers (Waters 1995). Fine

454 sediment fills in interstitial habitat in the substrate and decreases oxygen availability, subsequently 
456 taxa dominated burned watersheds, whereas unburned streams were dominated by sediment-

457 sensitive taxa (Arkle and others 2009). Sensitive taxa have been found in some streams scoured by

458 debris flows (Dunham and others 2007), but other evidence indicates that these channels can be

459 devoid of sensitive taxa (Cover and others 2010). Such evidence indicates that terrestrial processes

460 may contribute to extirpation of sensitive taxa and increase dominance of sediment-resistant taxa.

461 As terrestrial detritus can support detritivore production (Wallace and others 1999), expected

462 declines in detritivore populations due to warming (Boyero and others 2011) may be magnified by

463 lower inputs of organic matter. Wildfire reduced populations of taxa that specialize on terrestrial

464 detritus, increased populations of diet generalists (Mihuc and Minshall 1995; Minshall and others

465 2001), and increased reliance on autotrophic resources (Spencer and others 2003). Also, debris

466 flows largely extirpated detritivores, likely due to lower detritus availability (Cover and others 2010).

467 Reduced detrital inputs and retention may decrease production of obligate detritivores and increase

468 production of algivores or diet generalists that can exploit autotrophic resources (Table 2; Fig. 3).

469 Alteration of terrestrial processes may stimulate consumer production, increase the dominance of

470 disturbance-resistant taxa, and shift community composition toward algivores and diet generalists

471 (Table 3). Such a possibility is supported by greater secondary production and dominance of

472 disturbance-resistant taxa in desert streams, which often experience frequent floods, increased light

473 flux, and higher primary production (Jackson and Fisher 1986; Mulholland and others 2001). Given

474 considerable evidence that CC is increasing the frequency of these disturbances known to affect

475 consumer populations (Westerling and others 2006; Cover and others 2010; Romme and others

476 2011), these disturbances should be considered when assessing consumer responses to CC.

477 Ecosystem metabolism: Based on direct effects of temperature and flow, streams may become more

478 heterotrophic and exhibit lower net ecosystem production (NEP), the difference between ER and 
479 gross primary production (GPP) (Acuna and Tockner 2010; Yvon-Durocher and others 2010).

480 Warming can stimulate GPP and ER, but ER can exhibit larger increases (Yvon-Durocher and

481 others 2010). Conversely, more frequent winter floods may decrease GPP and ER because, in

482 general, they are negatively related to flood frequency (Uehlinger and Naegeli 1998). Yet, ER

483 declines may be smaller as it mostly occurs in the hyporheic zone, where it is less susceptible to

484 scour (Uehlinger and Naegeli 1998; Uehlinger 2000). Therefore, effects of more frequent floods and

485 warming may reinforce each other in the winter, decreasing GPP more than ER and increasing

486 heterotrophy (Table 3; Fig. 3). In contrast, GPP and autotrophy may increase as CC will likely

487 reduce summer baseflow (Young and others 2008; Marcarelli and others 2010). Despite contrasting

488 seasonal responses, CC has been predicted to decrease NEP (Yvon-Durocher and others 2010).

489 Shifts in terrestrial processes may alter metabolic responses because light and organic matter are

490 drivers of stream metabolism (Bott and others 1985; Mulholland and others 2001). A cross-biome

491 comparison showed that light, nutrients, and temperature explained 90\% of variation in GPP and

492 light alone explained 53\% of the variation in NEP (Mulholland and others 2001). For instance,

493 GPP was substantially lower in a coniferous forested stream $\left(77-148.3 \mathrm{~g} \mathrm{~m}^{-2} \mathrm{yr}^{-1}\right)$ than in Deep

494 Creek (3,540 $\left.\mathrm{g} \mathrm{m}^{-2} \mathrm{yr}^{-1}\right)$, an open-canopy shrub-grassland stream in Idaho (Minshall 1978; Webster

495 and Meyer 1997). In a forested stream of eastern North America that exhibits strong heterotrophy,

496 GPP increased after a spring freeze that delayed canopy closure and increased light flux (Mulholland

497 and others 2009). As light can promote post-scour recovery of GPP (Uehlinger 2000), reductions in

498 canopy cover due to CC may ameliorate expected declines in GPP due to frequent floods. In fact,

499 Sycamore Creek, which experiences frequent floods, was the only stream across many regions that

500 was autotrophic and had positive NEP, likely due to higher light flux (Mulholland and others 2001).

501 Conversely, increased sediment inputs and reduced organic matter inputs may attenuate light effects.

502 Sedimentation reduced light flux to the benthos, decreasing GPP and increasing heterotrophy during 
503 years with high flow and turbidity (Young and Huryn 1996). Reduced terrestrial organic matter

504 inputs also may reduce ER because organic matter standing crop can be a primary regulator of ER

505 (Roberts and others 2007). Differences in organic matter standing crop may be why ER was related

506 to temperature in one cross-biome comparison (Mulholland and others 2001), but not in another

507 (Bott and others 1985). Thus, CC-induced shifts in terrestrial processes may attenuate ER increases,

508 GPP reductions, and greater heterotrophy expected based on thermal and flow effects alone (Table

509 3; Fig. 3). However, there are substantial uncertainties in predicting responses of metabolism to

510 GCC, indicating the need for further studies that address both direct and indirect mechanisms.

511 Carbon export: Temperature and flow shifts may have contrasting effects on carbon export.

512 Downstream export may decline because higher temperatures can increase microbial respiration and

513 the proportion released as $\mathrm{CO}_{2}$ (Acuna and Tockner 2010; Yvon-Durocher and others 2010; Boyero

514 and others 2011). On the other hand, warming may increase export because greater microbial

515 production can be fueled by processing carbon stored in sediments (Acuna and Tockner 2010;

516 Gudasz and others 2010). A space-for-time comparison also found that carbon uptake was related

517 to periphyton biomass and stream width/depth ratio, but not temperature, light, or GPP (Marti and

518 others 2009). Therefore, faster processing due to warming may not be offset by uptake, reducing

519 retention efficiency. Because export is positively related to discharge (Wallace and others 1991) and

520 flow variability and high flows can alter carbon dynamics more than temperature (Acuna and

521 Tockner 2010), export may increase in the winter, but decrease in the summer. Greater flow

522 variability expected with rain-dominated hydrology may override warming effects (Table 3; Fig. 3).

523 Terrestrial processes may mediate responses of export expected based on temperature and flow

524 alone. Terrestrial detritus can be an important source of carbon pools and export (Webster and

525 Meyer 1997), so export may decline due to lower carbon inputs. Conversely, fewer wood inputs

526 may increase export because wood is important for organic matter retention in high-gradient streams 
527 of western North America (Megahan 1982; Gurnell and others 2002). Storage of sediment and

528 associated organic matter is positively related to instream wood volume (May and Gresswell 2003)

529 and wood stored 15-yrs of sediment and organic matter in Idaho streams (Megahan 1982). This

530 suggests that altered terrestrial processes may decrease export due to lower carbon inputs; buy may

531 increase it via declines in woody debris. Although the net response of export is unclear and requires

532 further study to fully assess, our analysis points to pathways by which terrestrial processes could

533 attenuate or magnify responses based on direct effects alone (Table 3; Fig. 3).

\section{Conclusion}

535 Results from our ecosystem model suggest that in ecoregions where CC is shifting ecosystem

536 distributions and increasing natural disturbance activity the effects of CC will not be limited to the

537 direct effects of changing temperature and flow. As changes in terrestrial processes are likely

538 altering the ecological context in which CC is occurring, such indirect effects need to be integrated

539 into our understanding of CC. However, our analysis identified uncertainties in some responses

540 (e.g., export and metabolism); thus, it highlights the need for further studies that explicitly assess

541 their responses to the direct and indirect effects of CC. Similar to the way that the incorporation of

542 disturbance regimes and vegetation changes can inform predictions about temperature increases and

543 the global carbon cycle (Goetz and others 2007; Kurz and others 2008), their incorporation may

544 improve understanding of how stream organisms and ecosystem processes will respond to CC.

545 Despite some difficulties in incorporating terrestrial processes into CC predictions, their exclusion

546 poses greater problems because CC is altering these processes known to influence streams.

547 Although our analysis focused on north temperate forested streams, CC is altering ecosystem

548 distributions and disturbance regimes in a variety of regions, indicating the broad applicability of our

549 approach. Similar analyses applied to other regions would further elucidate unanticipated effects of

550 CC on streams. For instance, wildfire activity is increasing globally (Flannigan and others 2009), as 
551 evidenced by predictions that wildfire area may increase 3-5× (Dury and others 2011) and fire return

552 intervals may shorten in the Mediterranean, changes that may eliminate woody species and convert

553 these ecosystems to grass-dominated ecosystems (Malkisnon and others 2011). Also, CC is expected

554 to increase the extent of insect outbreaks in a range of ecoregions, such as hemlock wooly adelgid

555 beetles (Adelges tsugae) in eastern North America and spruce bark beetles (Ips typographus) in Europe

556 (Jonsson and others 2007; Dukes and others 2009). Ecosystem boundaries also are projected to

557 move on a worldwide basis due to changes in climate and disturbance regimes (Frelich and Reich

558 2010; Gonzalez and others 2010), with evidence that shifts can sometimes occur rapidly (Turner

559 2010; Clifford and others 2011). As even small shifts in the composition of vegetation communities

560 may affect streams (Ball and others 2010), the effects of CC may be substantially underestimated

561 when terrestrial processes are not considered, even when CC does not lead to wholesale changes in

562 ecosystem distributions. Such widespread evidence indicates the importance of integrating both

563 potential direct and indirect effects of CC into predictive frameworks that assess stream responses.

\section{Acknowledgments}

565 This synthesis was made possible by funding from NSF Idaho EPSCoR (EPS 04-47689, EPS 08-

566 14387). It also benefited from discussions with our collaborators, A. Fremier, J. Hicke, B. Kennedy,

567 G. W. Minshall, and E. Yager, and comments from N. A. Griffiths and G. E. Small.

\section{References}

569 Acuna V, Tockner K. 2010. The effects of alterations in temperature and flow regime on organic

570 carbon dynamics in Mediterranean river networks. Global Change Biol. 16: 2638-2650.

571 Allen AP, Gillooly JF, Brown JH. 2005. Linking the global carbon cycle to individual metabolism.

$572 \quad$ Funct. Ecol. 19: 202-213.

573 Allen CD, Breshears DD. 1998. Drought-induced shift of a forest-woodland ecotone: rapid

574 landscape response to climate variation. Proc. Natl. Acad. Sci. USA 95: 14839-14842. 
575 Arkle RS, Pilliod DS, Strickler K. 2009. Fire, flow and dynamic equilibrium in stream

576 macroinvertebrate communities. Freshwat. Biol. 55: 299-314.

577 Arno SF, Simmerman DG, Keane RE. 1985. Forest succession on four habitat types in western

578 Montana, INT-GTR-177. Ogden, UT: U.S. Forest Service, Intermountain Research Station.

579 Baker WL. 2006. Fire and restoration of sagebrush ecosystems. Wildl. Soc. Bull. 34: 177-185.

580 Ball BA, Kominoski JS, Adams HE, Jones SE, Kane ES, Loecke TD, Mahaney WM, Martina JP,

581 Prather CM, Robinson TMP, Solomon CT. 2010. Direct and terrestrial vegetation-mediated

582 effects of environmental change on aquatic ecosystem processes. Bioscience 60: 590-601.

583 Barnett TP, Adam JC, Lettenmaier DP. 2005. Potential impacts of a warming climate on water

584 availability in snow-dominated regions. Nature 438: 303-309.

585 Behmer DJ, Hawkins CP. 1986. Effects of overhead canopy on macroinvertebrate production in a

$586 \quad$ Utah stream. Freshwat. Biol. 16: 287-300.

587 Beiswenger JM. 1991. Late quaternary vegetational history of Grays Lake, Idaho. Ecol. Monogr. 61:

$588 \quad 165-182$.

589 Benda L, Miller D, Sias J, Martin D, Bilby R, Veldhuisen C, Dunne T. 2003. Wood recruitment

590 processes and wood budgeting. Gregory S, Boyer KL, Gurnell AM, editors. Ecology and

591 Management of Wood in World Rivers Bethesda, MD: American Fisheries Society. p49-73.

592 Benke AC, Huryn AD. 2010. Benthic invertebrate production: facilitating answers to ecological

593 riddles in freshwater ecosystems. J. N. Am. Benthol. Soc. 29: 264-285.

594 Bentz BJ, Regniere J, Fettig CJ, Hansen EM, Hayes JL, Hicke JA, Kelsey RG, Negron JF, Seybold

595 SJ. 2010. Climate change and bark beetles of the western United States and Canada: direct and

596 indirect effects. Bioscience 60: 602-613.

597 Betts EF, Jones JB. 2009. Impact of wildfire on stream nutrient chemistry and ecosystem

598 metabolism in boreal forest catchments of interior Alaska. Arct. Antarct. Alp. Res. 41: 407-417. 
Biggs BJF, Smith RA, Duncan MJ. 1999. Velocity and sediment disturbance of periphyton in

600 headwater streams: biomass and metabolism. J. N. Am. Benthol. Soc. 18: 222-241.

601 Billings WD. 1994. Ecological impacts of cheatgrass and resultant fire on ecosystems in the western

602 Great Basin. Monsen SB, Kitchen SG, editors. Ecology and management of annual rangelands,

603 INT-GTR-313. Ogden, UT: U.S. Forest Service, Intermountain Research Station. p22-30.

604 Bilotta GS, Brazier RE. 2008. Understanding the influence of suspended solids on water quality and

605 aquatic biota. Water Res. 42: 2849-2861.

606 Booth MS, Stark JM, Rastetter E. 2005. Controls on nitrogen cycling in terrestrial ecosystems: a

607 synthetic analysis of literature data. Ecol. Monogr. 75: 139-157.

608 Bott TL, Brock JT, Dunn CS, Naiman RJ, Ovink RW, Petersen RC. 1985. Benthic community

609 metabolism in 4 temperate stream systems: an interbiome comparison and evaluation of the

610 river continuum concept. Hydrobiologia 123: 3-45.

611 Bowden WB, Gooseff MN, Balser A, Green A, Peterson BJ, Bradford J. 2008. Sediment and

612 nutrient delivery from thermokarst features in the foothills of the North Slope, Alaska: potential

613 impacts on headwater stream ecosystems. Journal of Geophysical Research-Biogeosciences 113.

614 Boyero L, Pearson RG, Gessner MO, Barmuta LA, Ferreira V, Graca MAS, Dudgeon D, Boulton

615 AJ, Callisto M, Chauvet E, Helson JE, Bruder A, Albarino RJ, Yule CM, Arunachalam M,

616 Davies JN, Figueroa R, Flecker AS, Ramirez A, Death RG, Iwata T, Mathooko JM, Mathuriau

617 C, Goncalves JF, Moretti MS, Jinggut T, Lamothe S, M'Erimba C, Ratnarajah L, Schindler MH,

618 Castela J, Buria LM, Cornejo A, Villanueva VD, West DC. 2011. A global experiment suggests

619 climate warming will not accelerate litter decomposition in streams but might reduce carbon

620 sequestration. Ecol. Lett. 14: 289-294.

621 Bradford MA, Davies CA, Frey SD, Maddox TR, Melillo JM, Mohan JE, Reynolds JF, Treseder KK,

622 Wallenstein MD. 2008. Thermal adaptation of soil microbial respiration to elevated temperature. 
Ecol. Lett. 11: 1316-1327.

624 Brooks PD, Williams MW. 1999. Snowpack controls on nitrogen cycling and export in seasonally

625 snow-covered catchments. Hydro. Process. 13: 2177-2190.

626 Brubaker LB. 1986. Responses of tree populations to climactic change. Vegetatio 67: 119-130.

627 Cannon SH. 2001. Debris-flow generation from recently burned watersheds. Environ. Eng. Geosci.

$628 \quad 7: 321-341$.

629 Clifford MJ, Cobb NS, Buenemann M. 2011. Long-term tree cover dynamics in a pinyon-juniper

630 woodland: climate-change-type drought resets successional clock. Ecosystems 14: 949-962.

631 Cook ER, Woodhouse CA, Eakin CM, Meko DM, Stahle DW. 2004. Long-term aridity changes in

632 the western United States. Science 306: 1015-1018.

633 Cover MR, de la Fuente JA, Resh VH. 2010. Catastrophic disturbances in headwater streams: the

634 long-term ecological effects of debris flows and debris floods in the Klamath Mountains,

635 northern California. Can. J. Fish. Aquat. Sci. 67: 1596-1610.

636 Dukes JS, Pontius J, Orwig D, Garnas JR, Rodgers VL, Brazee N, Cooke B, Theoharides KA,

637 Stange EE, Harrington R, Ehrenfeld J, Gurevitch J, Lerdau M, Stinson K, Wick R, Ayres M.

638 2009. Responses of insect pests, pathogens, and invasive plant species to climate change in the

639 forests of northeastern North America: what can we predict? Can. J. For. Res. 39: 231-248.

640 Dunham JB, Rosenberger AE, Luce CH, Rieman BE. 2007. Influences of wildfire and channel

641 reorganization on spatial and temporal variation in stream temperature and the distribution of

642 fish and amphibians. Ecosystems 10: 335-346.

643 Durance I, Ormerod SJ. 2007. Climate change effects on upland stream macroinvertebrates over a

644 25-year period. Global Change Biol. 13: 942-957.

645 Dury M, Hambuckers A, Warnant P, Henrot A, Favre E, Ouberdous M, Francois L. 2011.

646 Responses of European forest ecosystems to $21^{\text {st }}$ century climate: assessing changes in 
This is an author-produced, peer-reviewed version of this article. The final, definitive version of this document can be found online at

Ecosystems, published by Springer. Copyright restrictions may apply. DOI: 10.1007/s10021-013-9653-4.

interannual variability and fire intensity. Iforest-Biogeosciences and Forestry 4: 82-99.

648 Findlay S. 2010. Stream microbial ecology. J. N. Am. Benthol. Soc. 29: 170-181.

649 Fitzhugh RD, Driscoll CT, Groffman PM, Tierney GL, Fahey TJ, Hardy JP. 2001. Effects of soil

650 freezing disturbance on soil solution nitrogen, phosphorus, and carbon chemistry in a northern

651 hardwood ecosystem. Biogeochemistry 56: 215-238.

652 Flannigan MD, Krawchuk MA, de Groot WJ, Wotton BM, Gowman LM. 2009. Implications of

653 changing climate for global wildland fire. Int. J. Wildland Fire 18: 483-507.

654 Francoeur SN, Biggs BJF. 2006. Short-term effects of elevated velocity and sediment abrasion on

655 benthic algal communities. Hydrobiologia 561: 59-69.

656 Frelich LE, Reich PB. 2010. Will environmental changes reinforce the impact of global warming on

657 the prairie-forest border of central North America? Front. Ecol. Environ. 8: 371-378.

658 Gedalof Z, Peterson DL, Mantua NJ. 2005. Atmospheric, climatic, and ecological controls on

659 extreme wildfire years in the northwestern United States. Ecol. Appl. 15: 154-174.

660 Goetz SJ, Mack MC, Gurney KR, Randerson JT, Houghton RA. 2007. Ecosystem responses to

661 recent climate change and fire disturbance at northern high latitudes: observations and model

662 results contrasting northern Eurasia and North America. Environ. Res. Lett. 2: 045031.

663 Gonzalez P, Neilson RP, Lenihan JM, Drapek RJ. 2010. Global patterns in the vulnerability of

664 ecosystems to vegetation shifts due to climate change. Global Ecol. Biogeogr. 19: 755-768.

665 Gresswell RE. 1999. Fire and aquatic ecosystems in forested biomes of North America. Trans. Am.

$666 \quad$ Fish. Soc. 128: 193-221.

667 Groffman PM, Hardy JP, Fashu-Kanu S, Driscoll CT, Cleavitt NL, Fahey TJ, Fisk MC. 2011. Snow

668 depth, soil freezing and nitrogen cycling in a northern hardwood forest landscape.

669 Biogeochemistry 102: 223-238.

670 Grove JM. 1988. The Little Ice Age. New York: Methuen and Co. 
This is an author-produced, peer-reviewed version of this article. The final, definitive version of this document can be found online at

Ecosystems, published by Springer. Copyright restrictions may apply. DOI: 10.1007/s10021-013-9653-4.

671 Gudasz C, Bastviken D, Steger K, Premke K, Sobek S, Tranvik LJ. 2010. Temperature controlled

672 organic carbon mineralization in lake sediments. Nature 466: 478-U473.

673 Gurnell AM, Piegay H, Swanson FJ, Gregory SV. 2002. Large wood and fluvial processes. Freshwat.

674 Biol. 47: 601-619.

675 Harper MP, Peckarsky BL. 2006. Emergence cues of a mayfly in a high-altitude stream ecosystem:

676 potential response to climate change. Ecol. Appl. 16: 612-621.

677 Hentschel K, Borken W, Zuber T, Bogner C, Huwe B, Matzner E. 2009. Effects of soil frost on

678 nitrogen net mineralization, soil solution chemistry and seepage losses in a temperate forest soil.

$679 \quad$ Global Change Biol. 15: 825-836.

680 Hogg ID, Williams DD. 1996. Response of stream invertebrates to a global-warming thermal

681 regime: An ecosystem level manipulation. Ecology 77: 395-407.

682 Huerta MA, Whitlock C, Yale J. 2009. Holocene vegetation-fire-climate linkages in northern

683 Yellowstone National Park, USA. Palaeogeogr., Palaeoclimatol., Palaeoecol. 271: 170-181.

684 Hynes HBN. 1975. The stream and its valley. Verh. Internat. Verein. Limnol. 19: 1-15.

685 Isaak DJ, Luce CH, Rieman BE, Nagel DE, Peterson EE, Horan DL, Parkes S, Chandler GL. 2010.

686 Effects of climate change and wildfire on stream temperatures and salmonid thermal habitat in a

687 mountain river network. Ecol. Appl. 20: 1350-1371.

688 Izagirre O, Agirre U, Bermejo M, Pozo J, Elosegi A. 2008. Environmental controls of whole-stream

689 metabolism identified from continuous monitoring of Basque streams. J. N. Am. Benthol. Soc.

$690 \quad 27: 252-268$.

691 Jackson JK, Fisher SG. 1986. Secondary production, emergence, and export of aquatic insects of a

$692 \quad$ sonoran desert stream. Ecology 67: 629-638.

693 Jones C, Lowe J, Liddicoat S, Betts R. 2009. Committed terrestrial ecosystem changes due to climate $694 \quad$ change. Nature Geosci. 2: 484-487. 
This is an author-produced, peer-reviewed version of this article. The final, definitive version of this document can be found online at

Ecosystems, published by Springer. Copyright restrictions may apply. DOI: 10.1007/s10021-013-9653-4.

695 Jones TA, Daniels LD. 2008. Dynamics of large woody debris in small streams disturbed by the

6962001 Dogrib fire in the Alberta foothills. For. Ecol. Manage. 256: 1751-1759.

697 Jonsson AM, Harding S, Barring L, Ravn HP. 2007. Impact of climate change on the population

698 dynamics of Ips typographus in southern Sweden. Agric. For. Meteor. 146: 70-81.

699 Justus J. 2005. Qualitative scientific modeling and loop analysis. Philosophy of Science 72: 1272-

$700 \quad 1286$.

701 Kaushal SS, Likens GE, Jaworski NA, Pace ML, Sides AM, Seekell D, Belt KT, Secor DH, Wingate

702 RL. 2010. Rising stream and river temperatures in the United States. Front. Ecol. Environ. 8:

$703 \quad 461-466$.

704 Kiffney PM, Richardson JS, Bull JP. 2004. Establishing light as a causal mechanism structuring

705 stream communities in response to experimental manipulation of riparian buffer width. J. N.

$706 \quad$ Am. Benthol. Soc. 23: 542-555.

707 Kirchner JW, Finkel RC, Riebe CS, Granger DE, Clayton JL, King JG, Megahan WF. 2001.

708 Mountain erosion over 10 yr, 10 k.y., and 10 m.y. time scales. Geology 29: 591-594.

709 Knowles N, Dettinger MD, Cayan DR. 2006. Trends in snowfall versus rainfall in the Western

$710 \quad$ United States. J. Clim. 19: 4545-4559.

711 Knutson KC, Pyke DA. 2008. Western juniper and ponderosa pine ecotonal climate-growth

712 relationships across landscape gradients in southern Oregon. Can. J. For. Res. 38: 3021-3032.

713 Kunkel ML, Pierce JL. 2010. Reconstructing snowmelt in Idaho's watershed using historic

$714 \quad$ streamflow records. Clim. Change 98: 155-176.

715 Kurz WA, Dymond CC, Stinson G, Rampley GJ, Neilson ET, Carroll AL, Ebata T, Safranyik L.

716 2008. Mountain pine beetle and forest carbon feedback to climate change. Nature 452: 987-990.

717 Larned ST. 2010. A prospectus for periphyton: recent and future ecological research. J. N. Am.

$718 \quad$ Benthol. Soc. 29: 182-206. 
This is an author-produced, peer-reviewed version of this article. The final, definitive version of this document can be found online at Ecosystems, published by Springer. Copyright restrictions may apply. DOI: 10.1007/s10021-013-9653-4.

719 Levins R. 1966. The strategy of model building in population biology. Am. Sci.: 421-431.

720 Likens GE, Bormann FH. 1974. Linkages between terrestrial and aquatic ecosystems. Bioscience 24:

$721 \quad 447-456$.

722 Malison RL, Baxter CV. 2010. Effects of wildfire of varying severity on benthic stream insect

723 assemblages and emergence. J. N. Am. Benthol. Soc. 29: 1324-1338.

724 Malkisnon D, Wittenberg L, Beeri O, Barzilai R. 2011. Effects of repeated fires on the structure,

725 composition, and dynamics of mediterranean maquis: short- and long-term perspectives.

$726 \quad$ Ecosystems 14: 478-488.

727 Marcarelli AM, Kirk RWV, Baxter CV. 2010. Predicting effects of hydrologic alteration and climate

728 change on ecosystem metabolism in a western U.S. river. Ecol. Appl. 20: 2081-2088.

729 Marti E, Fonolla P, von Schiller D, Sabater F, Argerich A, Ribot M, Riera JL. 2009. Variation in

730 stream $\mathrm{C}, \mathrm{N}$ and $\mathrm{P}$ uptake along an altitudinal gradient: a space-for-time analogue to assess

731 potential impacts of climate change. Hydro. Res. 40: 123-137.

732 May CL, Gresswell RE. 2003. Processes and rates of sediment and wood accumulation in headwater

733 streams of the Oregon Coast Range, USA. Earth Surf. Proc. Land. 28: 409-424.

734 McKinley DC, Rice CW, Blair JM. 2008. Conversion of grassland to coniferous woodland has

735 limited effects on soil nitrogen cycle processes. Soil Biol. Biochem. 40: 2627-2633.

736 Megahan WF. 1982. Channel sediment storage behind obstructions in forested drainage basins

737 draining the granitic bedrock of the Idaho batholith. Swanson FJ, Janda RJ, Dunne T, Swanson

738 DN, editors. Sediment budgets and routing in forested drainage basins, PNW-GTR-141: U.S.

739 Forest Service, Pacific Northwest Research Station. p114-121.

740 Meyer GA, Pierce JL, Wood SH, Jull AJT. 2001. Fire, storms, and erosional events in the Idaho

$741 \quad$ batholith. Hydro. Process. 15: 3025-3038.

742 Meyer GA, Wells SG, Balling RC, Jull AJT. 1992. Response of alluvial systems to fire and climate 
744 Meyer JL, J. B. Wallace, and S. L. Eggert. 1998. Leaf litter as a source of dissolved organic carbon in 745 streams. Ecosystems 1: 240-249.

746 Mihuc TB, Minshall GW. 1995. Trophic generalists vs. trophic specialists: implications for food web 747 dynamics in postfire streams. Ecology 76:2361-2372.

748 Miller D, Luce C, Benda L. 2003. Time, space, and episodicity of physical disturbance in streams.

$749 \quad$ For. Ecol. Manage. 178: 121-140.

750 Minshall GW. 1978. Autotrophy in stream ecosystems. Bioscience 28: 767-770.

751 Minshall GW, Brock JT, Varley JD. 1989. Wildfires and Yellowstone stream ecosystems. Bioscience $752 \quad 39: 707-715$.

753 Minshall GW, Petersen RC, Bott TL, Cushing CE, Cummins KW, Vannote RL, Sedell JR. 1992.

754 Stream ecosystem dynamics of the Salmon River, Idaho: An 8th order system. J. N. Am.

755 Benthol. Soc. 11: 111-137.

756 Minshall GW, Robinson CT, Lawrence DE, Andrews DA, Brock JT. 2001. Benthic

757 macroinvertebrate assemblages in five central Idaho (USA) streams over a 10-year period

758 following disturbance by wildfire. Int. J. Wildland Fire 10: 201-213.

759 Moss B. 2010. Climate change, nutrient pollution and the bargain of Dr Faustus. Freshwat. Biol. 55:

$760 \quad 175-187$.

761 Mote PW, Salathe EP. 2010. Future climate in the Pacific Northwest. Clim. Change 102: 29-50.

762 Mulholland PJ, Fellows CS, Tank JL, Grimm NB, Webster JR, Hamilton SK, Marti E, Ashkenas L,

763 Bowden WB, Dodds WK, McDowell WH, Paul MJ, Peterson BJ. 2001. Inter-biome comparison

764 of factors controlling stream metabolism. Freshwat. Biol. 46: 1503-1517.

765 Mulholland PJ, Roberts BJ, Hill WR, Smith JG. 2009. Stream ecosystem responses to the 2007

766 spring freeze in the southeastern United States: unexpected effects of climate change. Global 
768 Nelson NA, Pierce J. 2010. Late-Holocene relationships among fire, climate and vegetation in a 769 forest-sagebrush ecotone of southwestern Idaho, USA. The Holocene 20: 1179-1194.

770 Oliver CD. 1981. Forest development in North America following major disturbances. For. Ecol.

$771 \quad$ Manage. 3: 153-168.

772 Pierce JL, Meyer GA, Jull AJT. 2004. Fire-induced erosion and millennial scale climate change in 773 northern ponderosa pine forests. Nature 432: 87-90.

774 Poff NL, Pyne MI, Bledsoe BP, Cuhaciyan CC, Carlisle DM. 2010. Developing linkages between 775 species traits and multiscaled environmental variation to explore vulnerability of stream benthic 776 communities to climate change. J. N. Am. Benthol. Soc. 29: 1441-1458.

777 Poff NL, Zimmerman JKH. 2010. Ecological responses to altered flow regimes: a literature review 778 to inform the science and management of environmental flows. Freshwat. Biol. 55: 194-205. 779 Raffa KF, Aukema BH, Bentz BJ, Carroll AL, Hicke JA, Turner MG, Romme WH. 2008. Cross780 scale drivers of natural disturbances prone to anthropogenic amplification: the dynamics of bark 781 beetle eruptions. Bioscience 58: 501-517.

782 Roberts BJ, Mulholland PJ, Hill WR. 2007. Multiple scales of temporal variability in ecosystem 783 metabolism rates: results from 2 years of continuous monitoring in a forested headwater stream. $784 \quad$ Ecosystems 10: 588-606.

785 Robinson CT, Minshall GW. 1998. Macroinvertebrate communities, secondary production, and life 786 history patterns in two adjacent streams in Idaho, USA. Arch. Hydrobiol. 142: 257-281.

787 Robinson CT, Uehlinger U, Minshall GW. 2005. Functional characteristics of wilderness streams 788 twenty years following wildfire. West. N. Am. Nat. 65: 1-10.

789 Romme W, Boyce M, Gresswell R, Merrill E, Minshall G, Whitlock C, Turner M. 2011. Twenty 790 years after the 1988 Yellowstone fires: lessons about disturbance and ecosystems. Ecosystems 
This is an author-produced, peer-reviewed version of this article. The final, definitive version of this document can be found online at Ecosystems, published by Springer. Copyright restrictions may apply. DOI: 10.1007/s10021-013-9653-4.

14: 1196-1215.

792 Rood SB, Pan J, Gill KM, Franks CG, Samuelson GM, Shepherd A. 2008. Declining summer flows

793 of Rocky Mountain rivers: changing seasonal hydrology and probable impacts on floodplain

794 forests. J. Hydrol. 349: 397-410.

795 Rosenzweig C, Karoly D, Vicarelli M, Neofotis P, Wu QG, Casassa G, Menzel A, Root TL, Estrella

796 N, Seguin B, Tryjanowski P, Liu CZ, Rawlins S, Imeson A. 2008. Attributing physical and

797 biological impacts to anthropogenic climate change. Nature 453: 353-U320.

798 Royer TV, Minshall GW. 1997. Temperature patterns in small streams following wildfire. Arch.

799 Hydrobiol. 140: 237-242.

800 Sand-Jensen K, Pedersen NL, Sondergaard M. 2007. Bacterial metabolism in small temperate

801 streams under contemporary and future climates. Freshwat. Biol. 52: 2340-2353.

802 Schmidt KM, Roering JJ, Stock JD, Dietrich WE, Montgomery DR, Schaub T. 2001. The variability

803 of root cohesion as an influence on shallow landslide susceptibility in the Oregon Coast Range.

804 Can. Geotech. J. 38: 995-1024.

805 Shafer SL, Bartlein PJ, Thompson RS. 2001. Potential changes in the distributions of western North

806 America tree and shrub taxa under future climate scenarios. Ecosystems 4: 200-215.

807 Spencer CN, Gabel KO, Hauer FR. 2003. Wildfire effects on stream food webs and nutrient

808 dynamics in Glacier National Park, USA. For. Ecol. Manage. 178: 141-153.

809 Spracklen DV, Mickley LJ, Logan JA, Hudman RC, Yevich R, Flannigan MD, Westerling AL. 2009.

810 Impacts of climate change from 2000 to 2050 on wildfire activity and carbonaceous aerosol

811 concentrations in the western United States. J. Geophys. Res. Atmos. 114: D20301.

812 Stephan K, Kavanagh KL, Koyama A. 2012. Effects of spring prescribed burning and wildfires on

813 watershed nitrogen dynamics of central Idaho headwater areas. For. Ecol. Manage. 263: 240-252.

814 Stewart IT. 2009. Changes in snowpack and snowmelt runoff for key mountain regions. Hydro. 
816 Stewart IT, Cayan DR, Dettinger MD. 2004. Changes in snowmelt runoff timing in western North

817 America under a 'business as usual' climate change scenario. Clim. Change 62: 217-232.

818 Svenson LO. 2010. Fire and climate in a lodgepole forest of central Idaho: annual, decadal,

819 centennial, and millenial perspectives. M.Sc. thesis. Boise State University.

820 Sweeney BW. 1978. Bioenergetic and development response of a mayfly to thermal variation.

821 Limnol. Oceanogr. 23: 461-477.

822 Sweeney BW, Jackson JK, Newbold JD, Funk DH. 1992. Climate change and the life histories and 823 biogeography of aquatic insects in eastern North America. Firth P, Fisher SG, editors. Global 824 climate change and freshwater ecosystems. New York: Springer-Verlag. p143-175.

825 Thackeray SJ, Sparks TH, Frederiksen M, Burthe S, Bacon PJ, Bell JR, Botham MS, Brereton TM, 826 Bright PW, Carvalho L, Clutton-Brock TIM, Dawson A, Edwards M, Elliott JM, Harrington R, 827 Johns D, Jones ID, Jones JT, Leech DI, Roy DB, Scott WA, Smith M, Smithers RJ, Winfield IJ, 828 Wanless S. 2010. Trophic level asynchrony in rates of phenological change for marine, 829 freshwater and terrestrial environments. Global Change Biol. 16: 3304-3313.

830 Turner MG. 2010. Disturbance and landscape dynamics in a changing world. Ecology 91: 2833-

8312849.

832 Uehlinger U. 2000. Resistance and resilience of ecosystem metabolism in a flood-prone river system.

$833 \quad$ Freshwat. Biol. 45: 319-332.

834 Uehlinger U, Naegeli MW. 1998. Ecosystem metabolism, disturbance, and stability in a prealpine 835 gravel bed river. J. N. Am. Benthol. Soc. 17: 165-178.

836 van Mantgem PJ, Stephenson NL, Byrne JC, Daniels LD, Franklin JF, Fule PZ, Harmon ME, 837 Larson AJ, Smith JM, Taylor AH, Veblen TT. 2009. Widespread increase of tree mortality rates 838 in the western United States. Science 323: 521-524. 
This is an author-produced, peer-reviewed version of this article. The final, definitive version of this document can be found online at

Ecosystems, published by Springer. Copyright restrictions may apply. DOI: 10.1007/s10021-013-9653-4.

839 Vieira NKM, Clements WH, Guevara LS, Jacobs BF. 2004. Resistance and resilience of stream

840 insect communities to repeated hydrologic disturbances after a wildfire. Freshwat. Biol. 49: 1243-

$841 \quad 1259$.

842 Vitousek PM, Reiners WA. 1975. Ecosystem succession and nutrient retention: a hypothesis.

$843 \quad$ Bioscience 25: 376-381.

844 Wallace JB, Cuffney TF, Webster JR, Lugthart GJ, Chung K, Goldowitz BS. 1991. Export of fine

845 organic particles from headwater streams: effects of season, extreme discharges, and invertebrate

846 manipulations. Limnol. Oceanogr. 36: 670-682.

847 Wallace JB, Eggert SL, Meyer JL, Webster JR. 1999. Effects of resource limitation on a detrital-

848 based ecosystem. Ecol. Monogr. 69: 409-442.

849 Waters TF. 1995. Sediment in streams: sources, biological effects, and control. Bethesda, MD USA:

$850 \quad$ American Fisheries Society Monograph 7.

851 Webster JR, Meyer JL. 1997. Stream organic matter budgets: introduction. J. N. Am. Benthol. Soc.

$852 \quad 16: 5-13$.

853 Westerling AL, Hidalgo HG, Cayan DR, Swetnam TW. 2006. Warming and earlier spring increase

854 western US forest wildfire activity. Science 313: 940-943.

855 Westerling AL, Turner MG, Smithwick EAH, Romme WH, Ryan MG. 2011. Continued warming

856 could transform Greater Yellowstone fire regimes by mid-21st century. Proc. Natl. Acad. Sci.

857 USA 108: 13165-13170.

858 Whitlock C, Briles CE, Fernandez MC, Gage J. 2011. Holocene vegetation, fire and climate history

859 of the Sawtooth Range, central Idaho, USA. Quatern. Res. 75: 114-124.

860 Williams AP, Allen CD, Millar CI, Swetnam TW, Michaelsen J, Still CJ, Leavitt SW. 2010. Forest

861 responses to increasing aridity and warmth in the southwestern United States. Proc. Natl. Acad.

862 Sci. USA. 
This is an author-produced, peer-reviewed version of this article. The final, definitive version of this document can be found online at Ecosystems, published by Springer. Copyright restrictions may apply. DOI: 10.1007/s10021-013-9653-4.

863 Williams JW, Jackson ST, Kutzbach JE. 2007. Projected distributions of novel and disappearing

864 climates by 2100 AD. Proc. Natl. Acad. Sci. USA 104: 5738-5742.

865 Wondzell SM, King JG. 2003. Postfire erosional processes in the Pacific Northwest and Rocky

866 Mountain regions. For. Ecol. Manage. 178: 75-87.

867 Woodward G, Perkins DM, Brown LE. 2010. Climate change and freshwater ecosystems: impacts

868 across multiple levels of organization. Philos. Trans. R. Soc. B: Biol. Sci. 365: 2093-2106.

869 Wu ZT, Dijkstra P, Koch GW, Penuelas J, Hungate BA. 2011. Responses of terrestrial ecosystems

870 to temperature and precipitation change: a meta-analysis of experimental manipulation. Global

$871 \quad$ Change Biol. 17: 927-942.

872 Young RG, Huryn AD. 1996. Interannual variation in discharge controls ecosystem metabolism

873 along a grassland river continuum. Can. J. Fish. Aquat. Sci. 53: 2199-2211.

874 Young RG, Matthaei CD, Townsend CR. 2008. Organic matter breakdown and ecosystem

875 metabolism: functional indicators for assessing river ecosystem health. J. N. Am. Benthol. Soc.

$876 \quad 27: 605-625$.

877 Yvon-Durocher G, Jones JI, Trimmer M, Woodward G, Montoya JM. 2010. Warming alters the

878 metabolic balance of ecosystems. Philos. Trans. R. Soc. B: Biol. Sci. 365: 2117-2126. 


\section{Table Legends:}

Table 1: Predicted stream responses to changes in temperature / precipitation regimes and terrestrial processes (i.e., wildfire, insect outbreaks, debris flows, and altered vegetation structure). Positive, negative, and neutral responses indicated by $(+),(-)$, and (0), respectively.

Table 2: Predicted stream responses to changes in temperature / precipitation regimes and terrestrial processes (i.e., wildfire, insect outbreaks, debris flows, and altered vegetation structure). Symbol designations as in Table 1.

Table 3: Predicted stream responses to changes in temperature / precipitation regimes and terrestrial processes (i.e., wildfire, insect outbreaks, debris flows, and altered vegetation structure). Symbol designations as in Table 1. 
Table 1

\begin{tabular}{ll}
\hline Stream parameter & Effects of temperature/precipitation \\
\hline Stream temperature & $(+)$ Increased atmospheric temperature \\
& will increase stream temperatures
\end{tabular}

Light flux

(0)

Nutrient input

Sediment input

Organic matter (OM)

input

Large-woody debris

(LWD) input

(+) Reduced winter snowpack that increases soil freezing will increase soil nutrient leaching and inputs to streams

(0)
Effects of terrestrial processes

\section{Net Response}

(+) Terrestrial processes that reduce canopy cover will increase stream temperatures

(+) Terrestrial processes that reduce canopy cover will increase light availability

(0) Terrestrial processes can increase short-term inputs, but have no effect over long-term

(+) Greater disturbance activity will increase long-term sediment inputs, especially when forests don't regeneratre

(+) If forests regenerate, greater disturbance activity will increase OM inputs

(-) If forests do not regenerate, greater disturbance activity will reduce inputs of terrestrial $\mathrm{OM}$
(+) Terrestrial processes will reinforce temperature responses, warming streams more than direct effects alone

(+) Terrestrial processes will be more important, increasing light flux more than direct effects alone

(+) Temperature/precipitation effects will be more important, increasing nutrient inputs

(+) Terrestrial processes will be more important than direct effects, increasing sediment inputs more than direct effects alone

(-) Terrestrial processes will be more important, decreasing OM inputs more than direct effects alone

(-) Terrestrial processes will be more important, decreasing LWD inputs more than direct effects alone
$(+)$ If forests regenerate, greater disturbance activity will increase LWD inputs

$(-)$ If forests do not regenerate, greater disturbance activity will reduce LWD inputs 
Table 2

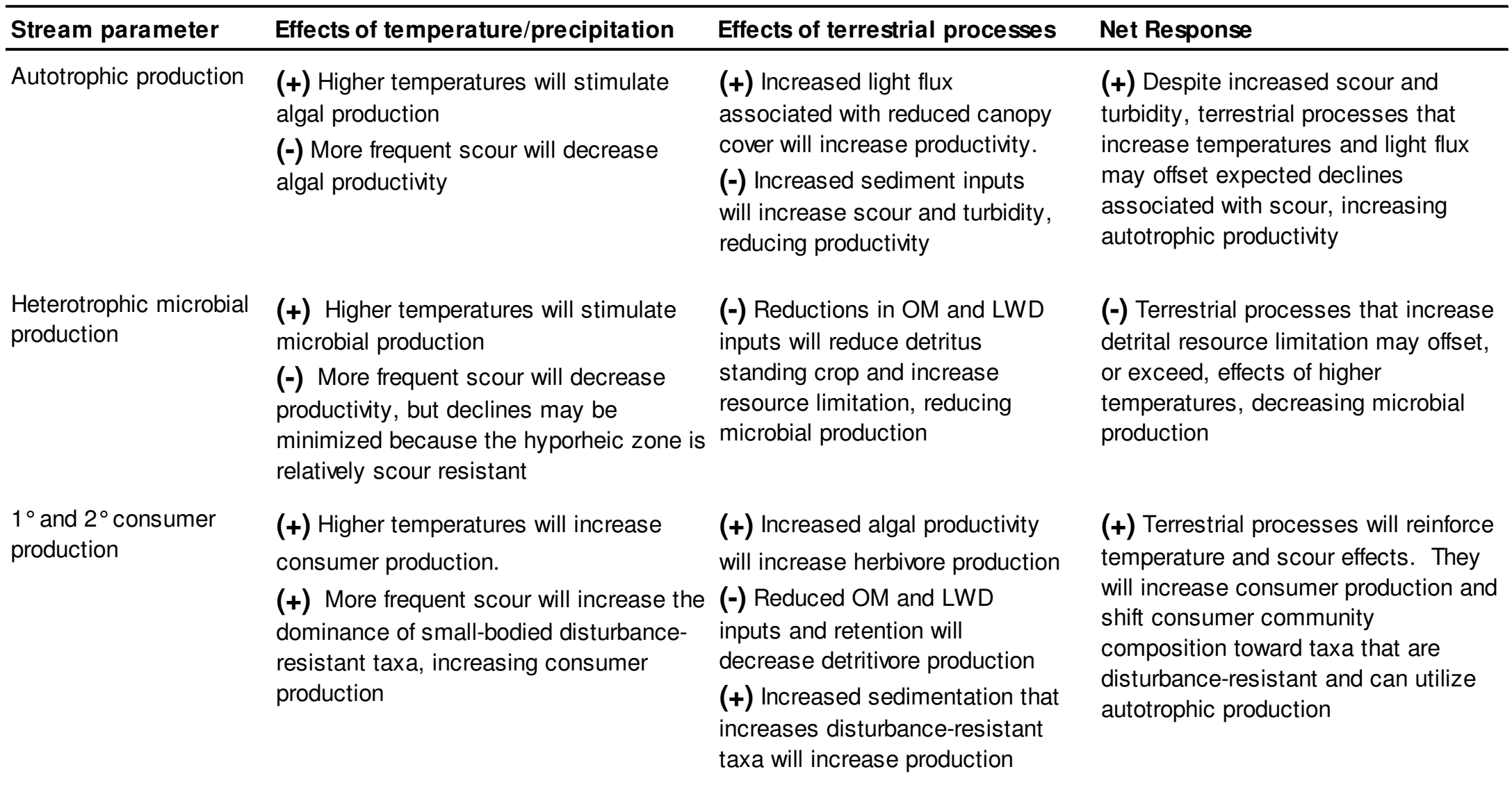


Table 3

\begin{tabular}{|c|c|c|c|}
\hline Stream parameter & Effects of temperature/precipitation & Effects of terrestrial processes & Net Response \\
\hline $\begin{array}{l}\text { Net ecosystem } \\
\text { production (NEP) }\end{array}$ & $\begin{array}{l}\text { (-) Higher temperatures will increase } \\
\text { ecosystem respiration (ER) more than } \\
\text { gross primary production (GPP), } \\
\text { decreasing NEP } \\
\text { (-) More frequent winter scour will reduce } \\
\text { GPP more than ER, decreasing winter } \\
\text { NEP } \\
\text { (+) Lower summer baseflow may } \\
\text { increase GPP more than ER, increasing } \\
\text { summer NEP }\end{array}$ & $\begin{array}{l}\text { (+) Increased light flux will } \\
\text { increase GPP more than ER, } \\
\text { increasing NEP } \\
(-) \text { Increased sediment inputs } \\
\text { will increase turbidity, } \\
\text { attenuating light-induced } \\
\text { increases in GPP and } \\
\text { decreasing NEP }\end{array}$ & $\begin{array}{l}\text { (+) Increased light flux and lower base } \\
\text { flows may offset expected NEP } \\
\text { declines due to temperature } \\
\text { increases, increasing NEP } \\
\text { (-) If increased turbidity attenuates } \\
\text { light to the substrate, terrestrial } \\
\text { processes may reinforce temperature } \\
\text { and scour responses, decreasing NEP }\end{array}$ \\
\hline Carbon export & $\begin{array}{l}\text { (+) Higher temperatures can increase } \\
\text { microbial processing of stored benthic } \\
\text { carbon, increasing downstream export } \\
\text { (+) Shifts to a rain-dominated hydrology } \\
\text { that increase winter baseflow will } \\
\text { increase winter carbon export } \\
(-) \text { Shifts to a rain-dominated hydrology } \\
\text { that decrease summer baseflow may } \\
\text { decrease summer export }\end{array}$ & $\begin{array}{l}\text { (-) Reductions in terrestrial OM } \\
\text { inputs will reduce sources of } \\
\text { stream carbon, reducing export } \\
\text { (+) Reductions in terrestrial } \\
\text { LWD inputs will reduce } \\
\text { structures important for carbon } \\
\text { retention, increasing carbon } \\
\text { export }\end{array}$ & $\begin{array}{l}\text { (+) Fewer retention structures may } \\
\text { magnify effects of winter scour and } \\
\text { temperature, increasing carbon export } \\
\text { (-) Reductions in terrestrial OM may } \\
\text { reinforce declines due to lower } \\
\text { summer baseflow, decreasing export }\end{array}$ \\
\hline
\end{tabular}




\section{Figure Legends}

Fig. 1: Conceptual model of the direct and indirect effects of climate change (CC) on stream structure and function. CC will alter temperature and precipitation regimes, with consequences for stream ecosystems. However, expected shifts in temperature and precipitation regimes will increase the frequency and spatial extent of terrestrial disturbances (e.g., drought, wildfire, debris flows, and insect outbreaks) that will change terrestrial ecosystem regeneration and structure. These shifts in terrestrial processes will alter terrestrially-derived resource inputs (i.e., run-off, nutrients, sediment, light, and organic matter). Arrow widths are proportional to expected effects. Dotted arrow represents the coupling of atmospheric temperature and precipitation regime responses.

Fig. 2: Projected response and recovery of (A) light flux, (B) sediment inputs, and (C) large wood inputs under past climate conditions that facilitated forest regeneration post-disturbance (typically within ca. 100-200 years; dotted line) versus when forest is converted to shrub-steppe ecosystem (solid line). Solid arrows represent the initial wildfire, while dotted arrows represent subsequent wildfires if forests are converted to shrub-steppe ecosystems (ca. $70 \mathrm{yr}$ fire return interval).

Fig. 3: Ecosystem model indicating pathways by which CC-induced shifts in temperature, precipitation, and terrestrial processes (e.g., disturbance regimes and ecosystem distributions) may alter streams. For each pairwise comparison that described the effect of a factor on a response variable, we assessed whether the effect was positive (green arrow), negative (red arrow), or neutral (black arrow) during the period of response (150-200 years). Dotted arrows were used when an effect existed, but its direction was unknown. By summing the various factors (i.e., arrows) affecting a given response, we predicted if it would increase (green box) or decrease (red box) when all direct and indirect pathways were considered. We could not predict directions of change for all arrows affecting a response. However, when the unknown arrows were unlikely to offset known effects, predictions were made based on stream ecology principles and shading indicated lower confidence. 


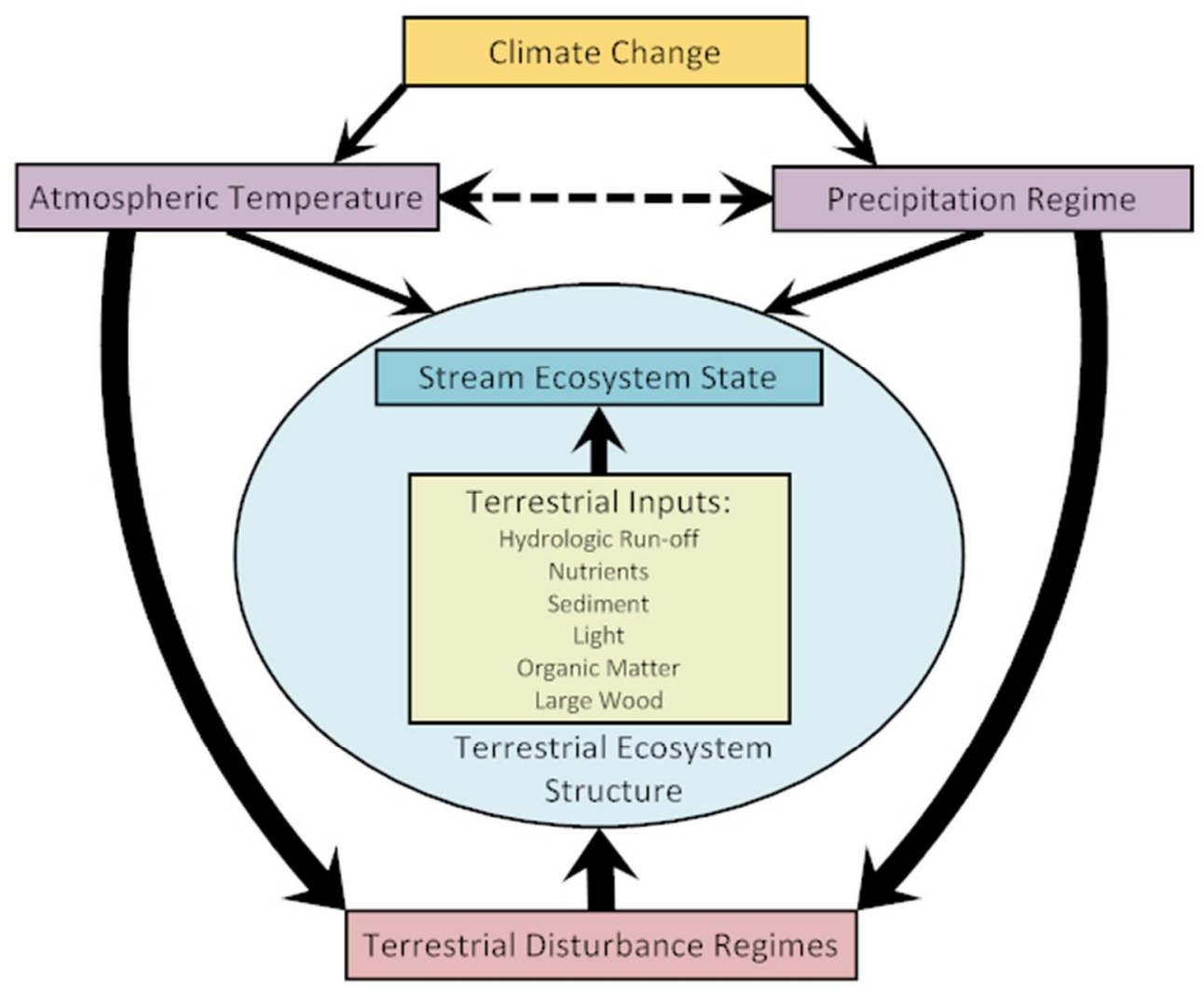

$54 \times 45 \mathrm{~mm}(300 \times 300 \mathrm{DPI})$ 

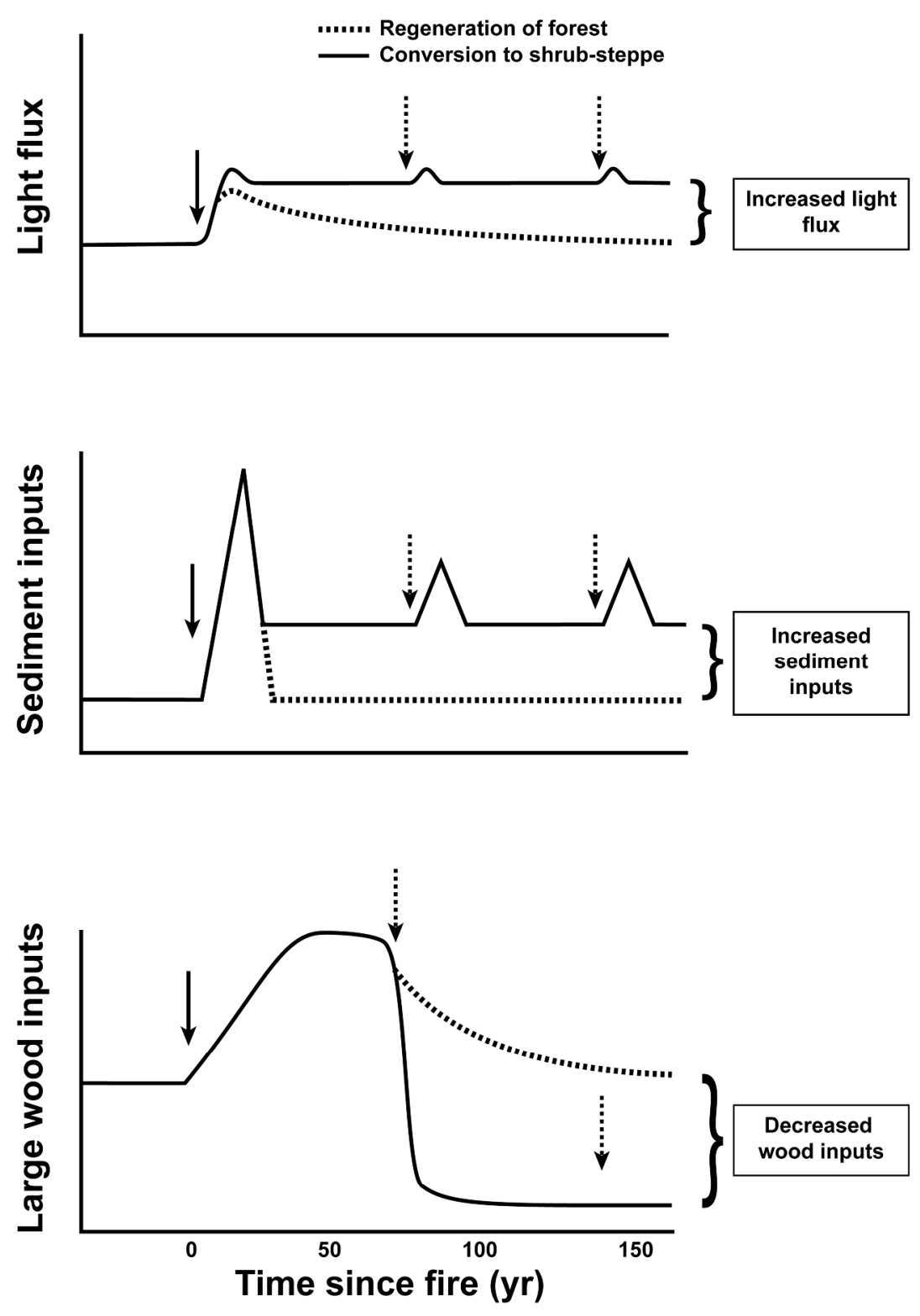

$237 \times 335 \mathrm{~mm}(300 \times 300 \mathrm{DPI})$ 


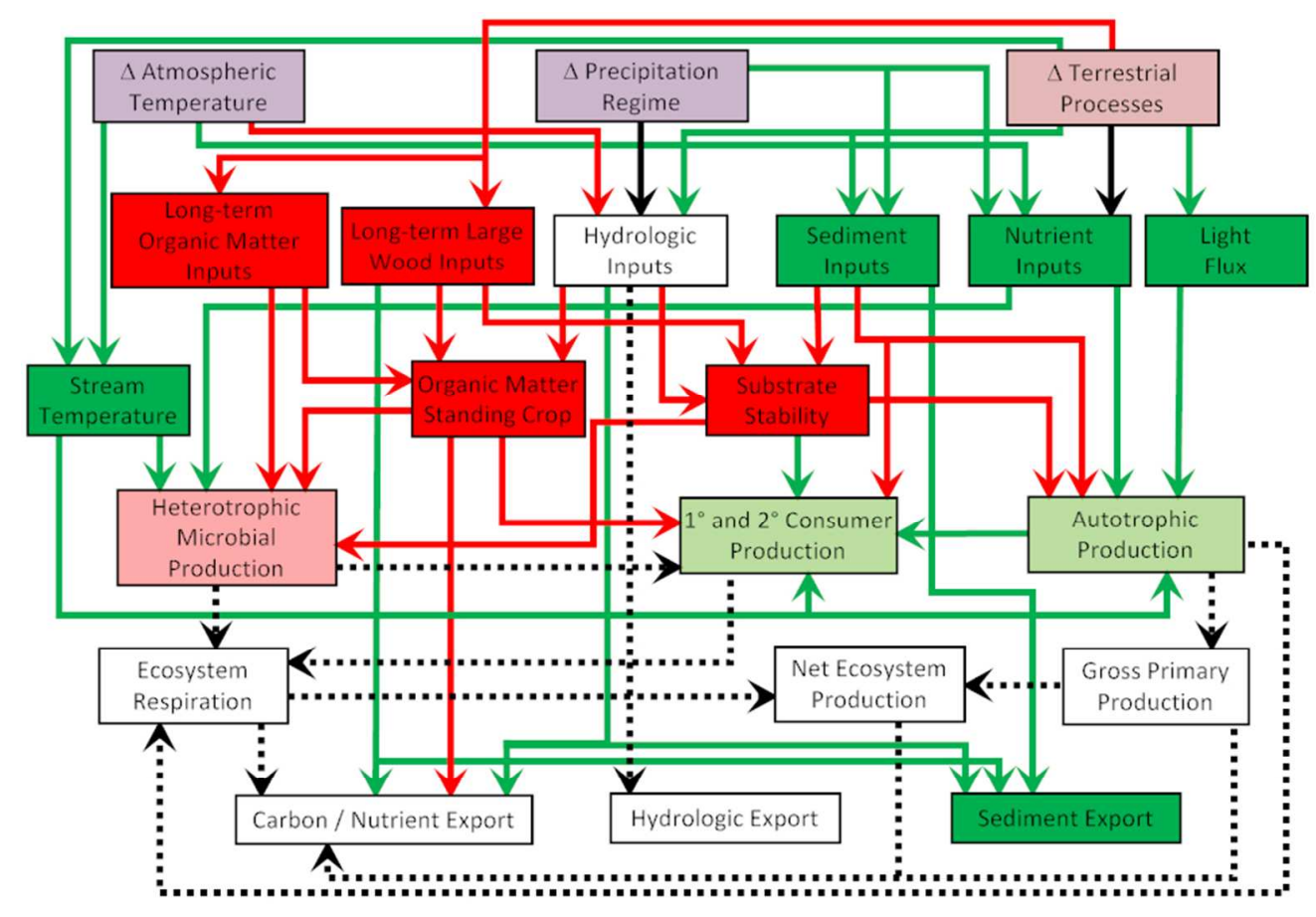

$81 \times 56 \mathrm{~mm}(300 \times 300$ DPI $)$ 